\title{
МЕЖДУНАРОДНЫЕ ОТНОШЕНИЯ
}

УДК 94(47+57)“1979”:327.8

ББК 63.3(2)633-64

\section{ИРАНСКАЯ РЕВОЛЮЦИЯ 1979 ГОДА И СОВЕТСКО-АМЕРИКАНСКИЕ ОТНОШЕНИЯ}

\author{
Г.Р. Муртазаева
}

\begin{abstract}
В статье анализируется воздействие Иранской революции 1979 г. на советско-американские отношения. Оцениваются позиции США и СССР в период американо-иранского кризиса.
\end{abstract}

\begin{abstract}
Ключевые слова: иранская революция, советско-американские отношения, американо-иранский кризис, внешняя политика СССР, внешняя политика США.
\end{abstract}

Самыми обсуждаемыми темами политических дискуссий последнего времени является серия революций, охвативших в начале 2011 г. Северную Африку и Ближний Восток, влияние этих революционных событий на внешнюю политику России и США, а также российско-американские отношения в их контексте.

Революция 1978-1979 гг. в Иране, которая стала самым важным событием в жизни этой страны и всего ближневосточного региона, также оказала значительное, как прямое, так и косвенное, влияние на внешнюю политику СССР и США и на советско-американские отношения.

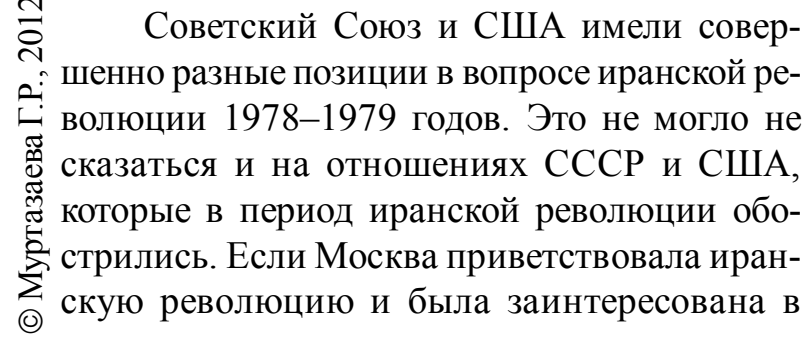

развитии всесторонних отношений с новым режимом, то для Вашингтона, который всячески пытался спасти шахский режим, победа иранской революции явилась крупным морально-политическим и военно-стратегическим поражением, ослабившим позицию США на Ближнем и Среднем Востоке и в развивающихся странах в целом.

Иранская революция не входила в расчет американцев, поэтому США пытались спасти проамериканский режим в Иране. Во время усиления накала революционной борьбы президент США Дж. Картер не раз заявлял о поддержке шаха, продавая Ирану очередную партию оружия и направляя в Аравийское море корабли американских военноморских сил [16, с. 115]. При всем при этом руководители вашингтонской администрации представляли дело так, будто США не вмешиваются и не намерены вмешиваться во внутренние дела Ирана.

В служебном донесении в МИД посольство СССР в США отмечало: «Режим шаха здесь традиционно рассматривают как залог надежности американо-иранского сотрудничества, как гарантию сохранения стратегичес- 
ких интересов США в регионе... Как считают в местных политических кругах, оппозиция по-прежнему разобщена из-за расхождения в желаниях и стремлениях... В целом, несмотря на обеспокоенность, вызванную ростом антишахского движения, американские политические обозреватели сходятся во мнении в том, что режим шаха еще способен справиться с трудностями, и его поддержка представляет на сегодняшний день единственно приемлемую для США политическую альтернативу» $[1$, с. 92$]$.

Что касается советского руководства, то оно внимательно следило за ходом революции в Иране. И конечно, американское вмешательство и концентрация военной силы США в Персидском заливе вызывали настороженность Москвы.

17 ноября 1978 г. Генеральный секретарь ЦК КПСС Л.И. Брежнев направил Дж. Картеру специальное послание по Ирану, где выразил «растущую озабоченность» по поводу того, что со стороны США предпринимались действия, имеющие целью «оказать влияние на происходящие события» в стране, которая непосредственно граничит с СССР и с которой у СССР сложились нормальные добрососедские отношения. Л.И. Брежнев предложил, чтобы СССР и США выступили с ясными и четкими заявлениями о «недопустимости вмешательства извне во внутренние дела Ирана» [8, c. 419].

В интервью газете «Правда» Генеральный секретарь ЦК КПСС заявил, что Советский Союз «против вмешательства извне во внутренние дела Ирана кого бы то ни было в любой форме и под каким бы то ни было предлогом. В этой стране имеют место события чисто внутреннего порядка, и решаться связанные с этим вопросы должны самими иранцами. ....Должно быть ясно и то, что любое, а тем более военное, вмешательство в дела Ирана - государства, которое непосредственно граничит с Советским Союзом, СССР рассматривал бы как затрагивающее интересы его безопасности» $[17$, с. 1$]$.

В ответ прозвучало заявление госдепартамента от имени госсекретаря Сайруса Вэнса, в котором подчеркивалось, что США не намерены вмешиваться во внутренние дела Ирана. Отмечалось, что подобное заявление сделал и СССР. Одновременно указывалось, что США «твердо поддерживают шаха в его усилиях по восстановлению внутреннего спокойствия в Иране» и намерены «сохранять прочные отношения с Ираном в политической и экономической областях и в вопросах безопасности» [8, с. 419].

Шах Ирана Мухаммед Реза Пехлеви потом писал: «Казалось, что русские обеспокоены происходящим в Иране больше, чем американцы. ....Седдиненные Штаты уклончиво согласились с позицией Советского Союза и сделали официальное заявление, в котором утверждалось, что ни при каких обстоятельствах Соединенные Штаты не будут вмешиваться в события в Иране. Что случилось с нашим двусторонним соглашением? Когда английские и американские послы снова пришли заверять меня в их поддержке, я не знал, какой я должен был сделать вывод из этих разных сообщений. Запад все еще настаивал, чтобы я продолжил программу либерализации, пока сохранялись закон и порядок. К сожалению, либерализация, проводимая с оружием, нацеленным в чью-то голову, по существу ограничена» $[31$, p. 170].

Как писал доцент политологии Университета штата Огайо Ричард Херман: «...c ноября 1978 до февраля 1979 Москва неоднократно предупреждала Соединенные Штаты против прямого вмешательства, но очень сомнительно, что это советское положение фактически удержало американское нападение» [33, p. 75]. По мнению автора, Вашингтон не решился на операцию по перевороту из-за ситуации в Иране, «а не из страха советской враждебности» [ibid.]. Хотя Ричард Херман не исключал возможности, что «внимание, обращенное советскими средствами массовой информации», которые в январе 1979 г. предупредили о неизбежном американском перевороте в Иране [10, с. $4 ; 18$, с. $5 ; 20$, с. 5$]$, сделало более рискованным выбор американской администрацией в пользу переворота [33, p. 75].

В свою очередь американская печать винила московское радио в росте антиамериканских настроений в Иране, французская писала о «сотнях советских агентов» в Иране и тысячах провокаторов, «подготовленных Москвой» [18, с. 5]. Спецслужбы США прибегали к публикациям фальшивок, пытаясь с 
их помощью доказать причастность Советского Союза к событиям в Иране $[19$, с. 5 ; 4, c. 84]. В них утверждалось, что к границе Ирана стянуты советские войска и уже убраны пограничные ограждения. Все это было направлено на то, чтобы оправдать наращивание военно-морского присутствия США в Персидском заливе. Государственный Департамент США также подал протест, жалуясь, что советские средства массовой информации подстрекали к насилию в Тегеране [33, p. 75].

Когда же стало очевидным, что дни шаха сочтены, Вашингтон стал налаживать неофициальные контакты с иранскими оппозиционными кругами с целью сформировать «центристское» гражданское правительство с включением в его состав «умеренных» оппозиционных сил [16, с. 116]. Одновременно США надеялись и на возможность организации военного заговора с целью обеспечить захват власти проамериканской милитаристской верхушкой [там же, с. 115-118].

В феврале 1979 г., после перехода власти в руки Временного революционного правительства, Вашингтон пытался объявить революцию в Иране следствием «козней Москвы». Но сразу после победы революции на одной из прессконференций представителя иранского правительства спросили, имело ли место воздействие СССР на ход событий, на что тот жестко ответил: «Мы не располагаем никакими фактами, свидетельствующими о хотя бы малейших попытках Советского Союза вмешаться в ход событий в Иране. Революцию в Иране совершил сам иранский народ» $[11$, с. 3$]$.

После победы революции руководители CССР, рассматривая события в Иране через призму противоборства с США, приветствовали свержение иранского проамериканского шахского режима. Ведь в результате революции США лишились крупного стратегического форпоста на Ближнем и Среднем Востоке, обеспечивавшего военное присутствие США на южных рубежах СССР.

А.А. Громыко в своей книге писал: «Не нам, не Советскому Союзу, сожалеть, что носитель шахской короны с завидной быстротой умчался за рубеж и кончил свой век в качестве изгнанника. Мы искренне приветствовали иранскую революцию и никогда не скрывали, что желаем поддерживать с Ираном дру- жественные, и только дружественные, отношения〉 [7, с. 99].

Как отметил профессор политологии колледжа Уильяма и Мэри Джеймс А. Билл, США, «испытав недостаток в эффективном контакте до революции», стали запоздало пытаться «наверстать упущенное время». А некоторые умеренные в правительстве Ирана считали поддержку США необходимой [30, p. 292]. В документах о встрече американского посла в Швеции Кеннеди Минотта (19771980) и иранского посла в Швеции Аббаса Амира Энтезама (сентябрь - октябрь 1979 г.) в Стокгольме говорится, что Энтезам выразил серьезное разочарование, что США отказываются принять иранскую революцию, и отметил, что США «заплатят высокую цену за эту выжидательную позицию» [35, p. 281]. Он также упомянул «о фундаментальном недоверии Советскому Союзу лидеров революции» и отметил активность советского посла в Тегеране, который ежедневно посещал правительственные министерства с предложениями всех видов помощи» [ibid.].

В ноябре 1979 г., когда начался ираноамериканский кризис, связанный с захватом 4 ноября группой иранских студентов посольства США в Тегеране, требующими выдать бывшего шаха Ирану для суда ${ }^{1}$, а также вернуть в Иран награбленные им богатства [14, c. 223], Вашингтон предпринял грубый нажим на Иран. Было объявлено о прекращении импорта в США иранской нефти, и были заморожены иранские счета в американских бан$\operatorname{rax}^{2}$. США сосредоточили в Аравийском море, вблизи Персидского залива, военно-морскую армаду в составе 26-30 боевых единиц, включая атомные авианосцы, на них находилось 24 тыс. американских военнослужащих.

Это вызвало беспокойство в Москве. Послу в Вашингтоне поручили встретиться со Зб. Бжезинским, советником президента по национальной безопасности, и предупредить, что если США действительно собираются пойти на какое-то военное вмешательство в Иране, то советская сторона не останется безразличной к этому и должна будет принять соответствующие меры [8, с. 452]. 3б. Бжезинский ответил, что у них нет каких-либо планов военного вторжения в Иран. Эти слова подтвердил госсекретарь Сайрус Вэнс, под- 


\section{МЕЖДУНАРОДНЫЕ ОТНОШЕНИЯ}

черкнув, что США не планируют прибегать к военным действиям, чтобы не ставить под угрозу жизнь заложников [8, с. 452].

Советское руководство по сути дела не осудило захват американских заложников иранскими студентами, хотя и охарактеризовало его как «акт, противоречащий международному праву» [24]. Так, оно отметило, что «Советский Союз испытывает глубокую симпатию к борьбе иранского народа за свои интересы, демократические права и подлинную независимость» [там же] и призвал к мирному урегулированию американо-иранского конфликта.

5 декабря на страницах «Правды» появилась статья «Проявлять благоразумие и сдержанность», где объяснялась позиция СССР: «Бесспорно, захват американского посольства сам по себе не соответствует Международной конвенции об уважении дипломатических привилегий и иммунитета. Нельзя, однако, вырывать этот акт из общего контекста американо-иранских отношений, забывать о действиях США в отношении Ирана, которые никак не согласуются с нормами права и морали... Бесспорность принципа неприкосновенности дипломатических представительств не может служить оправданием и еще меньше предлогом для нарушения суверенитета независимого государства - другого принципа, составляющего сердцевину всего международного права» $[21$, с. 5].

Являясь постоянным членом Совета Безопасности $\mathrm{OOH}$, Советский Союз совместно с другими членами Совета высказался за урегулирование американо-иранского конфликта с помощью политических средств, поддержал резолюцию Совета Безопасности от 4 декабря 1979 г. [25] и воздержался при принятии резолюции от 31 декабря [26]. В последней указывалось, что в случае невыполнения Ираном данной резолюции до 7 января 1980 г., будут приняты «эффективные меры в соответствии со статьями 39 и 41 Устава ООН» [23]. Эти меры не связаны с использованием вооруженных сил, но могут включать «полный или частичный перерыв экономических отношений, железнодорожных, морских, воздушных, почтовых, телеграфных, радио или других средств сообщения, а также разрыв дипломатических отношений» [27] с членами организации.
Представитель СССР в Совете Безопасности ООН О.А. Трояновский заявил, что «происходящее между Соединенными Штатами и Ираном является двусторонним спором», и «пристегивание к этому спору вопроса о каких-то санкциях необоснованно» [26].

В начале декабря Зб. Бжезинский попросил передать в Москву, что президент ценит поддержку, оказанную Советским Союзом в $\mathrm{OOH}$ при обсуждении вопроса об освобождении заложников в Тегеране, и благодарит за попытку СССР обратиться по дипломатическим каналам к иранскому руководству с советом избегать дальнейшего обострения обстановки и освободить американских заложников [там же].

Воспользовавшись ослаблением американского положения на Ближнем Востоке и тем, что США заняты освобождением заложников в Тегеране, СССР в декабре 1979 г. ввел войска в Афганистан, оправдывая свои действия соглашением о дружбе с кабульским режимом.

По мнению А.Ф. Добрынина, бывшего посла СССР в США, ввод в Афганистан советских войск обусловливался лишь угрозой безопасности южным советским границам ввиду нестабильности в Афганистане и Иране, желанием в силу этого подкрепить просоветский режим в Кабуле в противовес исламскому фундаментализму, который мог перекинуться в советские республики Средней Азии, а также марксистско-ленинской концепцией об «интернациональном долге». Плана стратегического наступления на интересы США в данном регионе разработано не было. Советское руководство рассчитывало на быстрые результаты, а не на десять лет затяжной гражданской войны [8, с. 454].

Но Г.М. Корниенко, бывший первый заместитель министра иностранных дел СССР, в своих мемуарах видел причину советского вторжения в Афганистан в том, что «...в связи с приходом к власти в Кабуле Амина у советского руководства возникли и все больше укреплялись опасения, что Афганистан может быть “потерян” для СССР и там могут обосноваться американцы, которых подталкивала к этому “утрата” ими Ирана...» $[15$, с. 195]

И если аятолла Хомейни первые три месяца молчал, будучи предупрежденным и 
имея договоренность с Москвой [5, с. 89-90], то потом, «поняв, что советские войска никак не могут выполнить то, зачем их туда послали» [там же, с. 90], выступил с резкой критикой в адрес СССР, называя ввод советских войск оккупацией Афганистана.

США это было воспринято «как попытка воспользоваться мучениями Запада и, возможно, даже захватить крупные месторождения нефти в Персидском заливе» [34, p. 10], что стало поводом для открытого перехода к политике антиразрядки и конфронтации между Советским Союзом и США.

Хотя Зб. Бжезинский в интервью 15 января 1998 г. заявил, что вторжение СССР в Афганистан спровоцировали Соединенные Штаты, когда 3 июля 1979 г. президент Дж. Картер подписал «первую директиву об оказании тайной помощи противникам просоветского режима в Кабуле», не исключая, что «эта помощь повлечет военное вмешательство СССР» [12]. Зб. Бжезинский отметил: «Мы не принуждали русских вмешиваться, но мы сознательно увеличили вероятность того, чтобы они это сделали» [там же].

23 января 1980 г. Дж. Картер направил Конгрессу традиционное послание «О положении в стране», где выдвинул новую внешнеполитическую доктрину. В ней провозглашалось, что «попытка какой-либо внешней силы установить контроль над районом Персидского залива будет рассматриваться как посягательство на жизненно важные интересы Соединенных Штатов, и такому посягательству будет дан отпор любыми необходимыми средствами, включая военную силу» [9]. Утверждая, что помощь СССР афганскому народу являлась следствием его «возросшей агрессивности» и направлена на создание «угрозы» интересам США и других стран - потребителей нефти, Дж. Картер объявил о введении «санкций» против СССР [там же]. Был заморожен договор ОСВ-2, введено эмбарго на поставки зерна в СССР. Американское правительство отказалось предоставить лицензии на уже оплаченное оборудование и технологии, запретило ловлю рыбы в прибрежных водах США. Было объявлено об отказе в проведении встреч по программам культурного, научного и других видов сотрудничества, бойкоте Олимпийских игр, проводимых летом 1980 г. в Москве [9].

Одной из основных тем официальных выступлений должностных лиц Белого дома и госдепартамента стала «реальная угроза» стабильности и целостности Ирана, исходящая от СССР. Администрация президента США в ухудшении международной обстановки в Персидском заливе винила СССР, говоря что «советская интервенция Афганистана может стать поводом для призывов к более решительным военным акциям в Иране. ...наша сдержанность будет ...преподноситься как мудрая, но излишне "застенчивая" позиция... Из-за продолжающейся нестабильности в Иране мы не имеем прочной преграды в Юго-Западной Азии на пути советского прорыва к Индийскому океану» [3, с. 46]. США «вынуждены» были разрабатывать новые стратегические концепции, к примеру, директиву № 59 президента Дж. Картера, предусматривавшую возможность ведения «ограниченной» ядерной войны, избирательных ударов по наиболее важным целям в СССР [32].

Анализируя ситуацию, созданную США, советское руководство указало в январе 1980 г., что Вашингтон снова пытается говорить с СССР языком «холодной войны». Было подчеркнуто, что действия американской администрации создают представление о Соединенных Штатах как о совершенно ненадежном партнере [6, с. 206].

После провала операции по вторжению «коммандос» на территорию ИРИ в конце апреля, когда погибли 8 американцев, Советский Союз осудил набег как опасную азартную игру, которая граничила с безумием и могла бы «привести к массовому кровопролитию» [29].

Позже США оказали давление на членов ЕЭС 22 мая 1980 г., чтобы они объявили экономический бойкот Ирану [13, с. 391], и к этому решению присоединились другие страны, в частности Япония, Австралия и Канада. Но Советский Союз и социалистические страны и государства, не присоединившиеся к бойкоту, стали поставлять Тегерану необходимое ему продовольствие, промышленные товары и оборудование. СССР разрешил Ирану транзит через свою территорию по водным и наземным путям, в том числе и по Транссибирской магистрали [28, с. 132]. 
Поняв, что экономическая блокада Ирана не сработала, Вашингтон был вынужден прибегнуть к дипломатическим методам решения вопроса об освобождении заложников, и соглашение об освобождении сотрудников американского посольства было подписано 19 января 1981 года. Формально американоиранский конфликт был улажен. Но кризис в американо-иранских отношениях не завершился освобождением американских дипломатов.

Таким образом, можно отметить, что у руководства СССР и США уже в конце 1978 начале 1979 г. сложилось разное отношение к событиям в Иране, и революция февраля 1979 г. только способствовала углублению кризиса в советско-американских отношениях. СССР приветствовал иранскую революцию, благодаря которой США потеряли контроль в зоне Персидского залива, а главное - военного союзника на южных рубежах СССР. Для США победа иранской революции стала крупным политическим и стратегическим поражением, пошатнувшим позицию Соединенных Штатов на Ближнем и Среднем Востоке.

Ввод Советским Союзом своих войск в Афганистан в период американо-иранского кризиса, связанного с американскими заложниками, еще больше усилил и без того имеющееся противостояние двух держав. Администрация Дж. Картера, опасаясь укрепления стратегической позиции СССР на Ближнем и Среднем Востоке, а также угрозы со стороны Советского Союза свободному движению нефти из этого региона и не желая мириться с ролью Советского Союза как равного партнера, второй сверхдержавы, начала разворачивать деятельность на всемерное усиление американского присутствия в Персидском заливе. Уже к концу 1979 г. стало ясно, что мир стоит на пороге новой гонки вооружений.

\section{ПРИМЕЧАНИЯ}

1 Только 2 ноября 1980 г. меджлис принял решение освободить заложников при условии возврата США имущества шаха, отказа от претензий к Ирану и разморозки иранских авуаров в американских банках. 19 января соглашение об урегулировании взаимных претензий было подписано. 21 января американские дипломаты вылетели из Ирана [13, с. 393; 22, с. 5$]$.
2 По сообщениям посольства СССР в США «замораживание банковских вкладов Ирана вызвало озабоченность со стороны стран - членов ОПЕК, выразивших опасения возможностью подобной же акции США по отношению к ним в случае какойлибо кризисной ситуации в районе Персидского залива в будущем. В результате в настоящее время страны ОПЕК предпочитают размещать свои нефтедоллары в европейских банках» [2, с. 89-92].

\section{СПИСОКЛИТЕРАТУРЫ}

1. Архив внешней политики РФ. - Ф. 129 (Год 1978). - Оп. 64. - Д. 31. - Папка 325.

2. Архив внешней политики РФ. - Ф. 129 (Год 1980). - Оп. 66. - Д. 68. - Папка 368.

3. Афганская карта : [докладная записка Зб. Бжезинского. Соображения о советском вторжении в Афганистан. 26.121979 г.] // Родина. - 1999. № 2. - С. $45-47$.

4. Богачев, В. И. Вмешательство США в Иране / В. И. Богачев // США: экономика, политика, идеология. - 1979. - № 3. - С. 83-84.

5. Виноградов, В. М. Эпизоды из дипломатической практики / В. М. Виноградов. - М. : Изд-во МГИМО, 1993.-336 с.

6. Внешняя политика Советского Союза / сост. В. П. Нихамин, А. Л. Адамишин, Е. Ю. Богуш [и др.] ; предисловие А. А. Громыко. - 3-е изд., перераб. и доп. - М. : Политиздат, 1985. - 399 с.

7. Громыко, А. А. Памятное : в 2 кн. / А. А. Громыко. - М. : Политиздат, 1988. - Кн. 2. $416 \mathrm{c}$.

8. Добрынин, А. Сугубо доверительно. Посол в Вашингтоне при шести президентах США (19621986 гг.) / А. Добрынин. - М. : Автор, 1996. - 688 с.

9. «Доктрина Картера». - Электрон. текстовые дан. - Режим доступа: http://www.coldwar.ru /bases/carter_doctrine.php. - Загл. с экрана.

10. Известия. $-1979 .-13$ янв. - С. 4.

11. Известия. - 1979. -21 февр. - С. 4.

12. Интервью с 3. Бжезинским (Z. Brzezinski) о том, как США спровоцировали Советский Союз на интервенцию в Афганистан («Le Nouvel Observateur», Франция). - Электрон. текстовые дан. - Режим доступа: http://m7k.narod.ru/williams /librar...ski-199803.html. - Загл. с экрана.

13. Иранская революция 1978-1979 гг. : Причины и уроки / отв. ред. А. 3. Арабаджян. - М. : Наука, 1989. - 556 с.

14. Комаров, В. Иран: победа революции, борьба за становление республиканского строя / В. Комаров // Международный ежегодник. Политика и экономика / АН СССР, Ин-т мировой экономики и междунар. отношений ; гл. ред. О. Н. Быков. - М. : Политиздат, 1980. - Вып. 1980. - С. 220-224. 


\section{МЕЖДУНАРОДНЫЕ ОТНОШЕНИЯ}

15. Корниенко, Г. М. «Холодная война»: свидетельство ее участника / Г. М. Корниенко. - М. : Междунар. отношения, 1994. - 288 с.

16. Кременюк, В. А. Борьба Вашингтона против революции в Иране / В. А. Кременюк. - М. : Междунар. отношения, 1984. - 175 с.

17. Правда. - 1978. - 19 нояб. -С. 1.

18. Правда. - 1979. - 11 янв. - С. 5.

19. Правда. - 1979. - 12 янв. - С. 5.

20. Правда. - 1979. - 13 янв. - С. 5.

21. Правда. - 1979. - 5 дек. - С. 5.

22. Правда. - 1981. -21 янв. - С. 5.

23. Резолюция № 461 (1979) от 31 дек. 1979 г. Электрон. текстовые дан. - Режим доступа: http: //www.un.org/russian/documen/scresol/1979 /res461.pdf. - Загл. с экрана.

24. Совет Безопасности ООН. Официальные отчеты. 2175 заседание. - 1 дек. 1979 года. - Электрон. текстовые дан. - Режим доступа: http://www.un.org/ru /documents/ods.asp?m=S/PV.2175(OR). - Загл. с экрана.

25. Совет Безопасности ООН. Официальные отчеты. 2178 заседание. - 4 дек. 1979 года. - Электрон. текстовые дан. - Режим доступа: http: //daccess-ods.un.org/TMP/1043771.20733261.html. Загл. с экрана.

26. Совет Безопасности ООН. Официальные отчеты. - 2184 заседание. - 31 дек. 1979 г. - Электрон. текстовые дан. - Режим доступа: http://daccessods.un.org/TMP/2992546.html. - Загл. с экрана.

27. Устав ООН. Ст. 39 и 41. - Электрон. текстовые дан. - Режим доступа: http://www.un.org/ru /documents/charter/chapter7.shtml. - Загл. с экрана.
28. Филиппов, А. Тегеран-79. Аятолла и крах шахского режима. Мемуары / А. Филиппов // Родина. - 2001. - № 5. - С. 127-132.

29. Eight Americans die in President's most disastrous night. - Electronic text data. - Mode of access: http://www.guardian.co.uk/world/1980/apr/26 /iran.fromthearchive. - Title from screen.

30. James, A. Bill. The Eagle and the Lion. The tragedy of American-Iranian relations / A. James. New Haven ; London : Yale University Press. Cop., 1988. $-520 \mathrm{p}$.

31. Mohammad Reza Pahlavi. Answer to history / Mohammad Reza Pahlavi ; by Mohammad Reza Pahlavi, the shah of Iran // Toronto; Vancouver : Clarke, Irwin and co., Cop, 1980.-204 p.

32. Page: Carter Presidential Directive 59, Nuclear Weapons Employment Policy.djvu/2. - Electronic text data. - Mode of access: http://en.wikisource.org/wiki /Page:Carter_Presidential_Directive_59,_Nu clear_Weapons_Employment_Policy.djvu/2. $-\bar{T}$ Title from screen.

33. Richard Herrmann. The role of Iran in Soviet Perceptions and Policy // Neither East nor West: Iran, the Soviet Union and the United States / ed. by Nikki R. Kedie and Mark J. Gasiorowski. - New Haven ; L. : Yale University Press. Copyright, 1990. - P. 74 -99.

34. The Soviet-American Competition in the Middle East / ed. by Steven L. Spiegel, Mark A. Heller, Jacob Goldberg. - Lexington. D. C. Health and Company, 1988. - 392 p.

35. The Tehran documents selected and edited by AHHAbidi. - New Delhi : Patriot Publishers, 1988. - 328p.

\section{THE IRANIAN REVOLUTION OF 1979 AND THE SOVIET-AMERICAN RELATIONS}

\section{G.R. Murtazaeva}

The article analyses the impact of the Iranian revolution of 1979 on the Soviet-American relations and estimates the position of the USA and the USSR in the period of the U.S.-Iranian crisis.

Key words: Iranian Revolution, Soviet-American relations, U.S.-Iranian crisis, foreign policy of the USSR, the U.S. foreign policy. 